\title{
Crust - mantle boundary beneath the Pripyat rift: Insights from minerals of hornblenditic xenoliths
}

\author{
G.D. VolKova ${ }^{1 *}$, A.A. Nosova ${ }^{1}$, A.A. VOZNYAK ${ }^{1}$, \\ L.V. SAZONOVA ${ }^{2}$, E.V. YUTKINA ${ }^{1}$, M.O. ANOSOVA ${ }^{3}$, \\ YA.S. TIKHOMIROVA ${ }^{3}$, O.F. KUZMENKOVA ${ }^{4}$, \\ A.G. LAPTSEVICH ${ }^{4}$ \\ ${ }^{1}$ Institute of Geology of Ore Deposits, Petrography, \\ Mineralogy and Geochemistry Russian Academy of \\ Sciences, Moscow, Russia (*correspondence: \\ earlinndrow@gmail.com) \\ ${ }^{2}$ Lomonosov Moscow State University, Moscow, Russia \\ ${ }^{3}$ Vernadsky Institute of Geochemistry and Analytical \\ Chemistry of Russian Academy of Sciences, Moscow, \\ Russia \\ ${ }^{4}$ Research and Production Center for Geology, Minsk, \\ Belarus
}

Hornblenditic xenoliths found in the Devonian alkaline volcanics of the continental Pripyat rift vary from pure hornblendites and clinopyroxene hornblendites through hornblende melagabbros to garnet-biotite-amphibole-shales. Similar xenoliths have been reported worldwide in either intraplate or suprasubduction settings.

After detailed study of petrography, mineral and bulkrock composition of the xenoliths, isotopic investigations, calculation of melts in equilibrium with amphiboles of the xenoliths, T-P estimations, and amphibole comparison with amphiboles of different tectonic settings, we found that pure hornblendites, clinopyroxene hornblendites and hornblende melagabbros represent lower crustal cumulates of the Devonian alkaline magmas, which were parential magmas for the host rocks (in case of pure hornblendite xenoliths) or more evolved derivative magmas (in other cases), while garnet-biotite-amphibole-shales were developed by Devonian metasomatic reworking of the subduction-related lower crustal granulites of the Pripyat rift. Previous ${ }^{40} \mathrm{Ar} /{ }^{39} \mathrm{Ar}$ studies [1] and our Sr-Nd data confirm Devonian ages of hornblendite, clinopyroxene hornblendite and hornblende melagabbro xenoliths and their belonging to their hosts, while Sr-Nd results for garnet-biotite-amphibole-shales show their affinity to the lower crustal granulites. Therefore, these xenoliths indicate that the lower crust nearby the crustmantle boundary beneath the Pripyat rift is composed of garnet granulites reworked by Devonian magmas and hornblenditic cumulates of such magmas. The study was funded by RFBR projects 17-05-00534 and 18-55-00006.

[1] Markwick, Downes, \& Veretennikov (2001) Tectonophysics 339, 215-237. 